\title{
Ryzhov V. \\ COMPUTER AND ANALYTICAL CALCULATIONS FOR OPTIMIZATION OF CYCLE SEPARATION OF ASH
}

Об'єктом дослідження є ефективність очистки димових газів в групових циклонах типу ЦН-15 діаметром 0,7 м парового котла КЕ 10-14-285 при спалюванні лузги соняшнику на олійно-жировому комбінаті. Однією з найбільших проблем різних технологій спалювання лузги соняшнику в котельних агрегатах на олійно-жирових комбінатах є низька ефективність вловлювання в типових циклонах золи лузги соняшнику через значну дисперсність золи та інших факторів.

Оцінка у роботі проводилася за рахунок використання розроблених аналітичних розрахункових моделей та компютерної технологї CFD (Coтputational Fluid Dynaтic) - сертифікованої комп'ютерної програми «SolidWorks-2009», на розрахунковому комплексі (КПI).

Наведені розрахункові та експериментальні дані з оцінки ефективності очищення димових газів у циклонах парового котла «КЕ 10-14-285» (Україна) при спалюванні лузги соняшнику на Вінницькому олійно-жировому комбінаті (Україна). Показана можливість значного зниження виносу золи в повітря при реконструкцї згідно нової технологї̈ групових циклонів типу ЦН-15 (Україна). За допомогою комп'ютерних та аналітичних розрахунків обгрунтована можливість підвищення загальної ефективності очистки димових газів від золи при спалюванні в котлах лузги соняшнику до рівня 90 \% замість 45...55\%.

В ході дослідження використовувалась технологія створення на ступеневій вхідній ділянці ииклонів високої інтенсивності турбулентності потоку при обтіканні різноманітних турбулізаторів. Завдяки даній технології забезпечується можливість зниження в більш ніж три рази винесення золи з ииклону у порівнянні з аналогічними показниками у типових циклонах до їх модернізації. Це дозволяє з мінімальними капітальними витратами задовільнити санітарні норми країн Свропейського Союзу та України. Такий результат досягається за рахунок ряду особливостей - зокрема, різкому підвищенню пульсацї складової швидкості потоку.

Ключеві слова: циклон парового котла «КЕ 10-14-285», інтенсивність турбулентності, генератор турбулентності, діаметр відсікання.

\section{Introduction}

The capture of finely dispersed ash in cyclones (with a median particle diameter of $5 . . .7$ microns and with a number of densities), when burning sunflower husks in boiler units, is associated with significant difficulties. This is due to the fact that the efficiency of cyclones in such conditions is insignificant and amounts to $45 . .55 \%$, on average, even with spherical combustion, and even lower with vortex combustion. In addition, the ash from burning sunflower husks has a complex non-spherical shape in the form of plates, which reduces the efficiency of cleaning cyclones.

At the same time, the final dust content of the sunflower husk ash in the flue gases was: with a spherical method of burning on gratings, $500 \ldots 600 \mathrm{bmg} / \mathrm{m}^{3}$, and with vortex burning - $1500 \mathrm{mg} / \mathrm{m}^{3}$. This significantly exceeds the requirements of sanitary standards of the EU and Ukraine $\left(50 \ldots 100 \mathrm{mg} / \mathrm{m}^{3}\right.$ - depending on the thermal capacity of steam boilers). Therefore, it is extremely important to develop various methods and technologies to increase the efficiency of ash collection in dust collectors when burning sunflower husks in boiler units.

\section{The object of research and its technological audit}

The object of research is the efficiency of flue gas cleaning in group cyclones of type $\mathrm{CN}-15$ with a diameter of $0.7 \mathrm{~m}$ steam boiler KE 10-14-285 when burning sunflower husks at an oil-fat plant.

An experimental verification of the results is carried out in the work - through the use of developed analytical and computer calculation models and the use of computer technology CFD - Computational Fluid Dynamic certified computer program «SolidWorks-2009», on the calculation complex (KPI).

One of the most problematic places of various technologies for burning sunflower husk in boiler units at oil and fat plants is the low efficiency of collecting sunflower husk ash in typical cyclones due to the significant dispersion of ash and other factors. For example, on a steam boiler of the KE 10-14-285 type (Ukraine) with a steam capacity of $10 \mathrm{t} / \mathrm{h}$ when cleaning in dry cyclones, the final dust content of gases is $500 \ldots 900 \mathrm{mg} / \mathrm{m}^{3}$. This is a significant drawback, since in the countries of the 
European Union (EU) and Ukraine sanitary standards are $100 \mathrm{mg} / \mathrm{nm}^{3}$ (for old boilers) and lower, depending on the actual physicochemical parameters of the ash, it captures the initial dustiness, dispersion, density.

\section{The aim and objectives of research}

The aim of research is development of a new method of gas cleaning in dry cyclones with the ball method of burning sunflower husks on grate grates in a steam boiler of the KE 10-14-285 type with a steam capacity of $10 \mathrm{t} / \mathrm{h}$. Using this method should increase the efficiency of cleaning from level $45 . .55 \%$ to the level of almost $90 \%$.

To achieve this aim, it is necessary to complete the following objectives:

1. To carry out analytical and computer calculations of the cleaning efficiency for industrial cyclones in the oil-fat factory.

2. To conduct an experimental verification of the introduction of a new ash cleaning technology when burning sunflower husks and the adequacy of computer and analytical methods for calculating the cleaning efficiency.

\section{Research of existing solutions of the problem}

Currently, in the field of flue gas cleaning from ash when burning renewable energy sources, for example, when burning sunflower husks in steam boilers, there is very limited information on ash cleaning systems:

- in cyclones [1];

- in electrostatic precipitators [2];

- in bag filters [3].

So, in [2] in the boiler room of EFKO OJSC (Oleksiivka, Russia) in a steam boiler No. 1 of the KE-16-23-370 type (Ukraine) with a steam capacity of $16 \mathrm{t} / \mathrm{h}$ with vortex burning of sunflower husk. The amount of flue gas $47034 \mathrm{~m}^{3} / \mathrm{h}\left(t_{g}=208{ }^{\circ} \mathrm{C}\right)$, the initial dust content of $3040 \mathrm{mg} / \mathrm{m}^{3}$. The flue gas cleaning efficiency in a group cyclone of nine $\mathrm{CN}-11$ cyclones (Ukraine) with a diameter of $1 \mathrm{~m}$ was $h=48 \%$, and the final dust content was $K_{\text {fin }}=1580 \mathrm{mg} / \mathrm{m}^{3}$ at a rate of $50 \mathrm{mg} / \mathrm{nm}^{3}$ [3, 4].

On a similar boiler No. 2 of the KE-16-23-370 type (Oleksiivka, Russia), after the introduction of the highly efficient dust collector of the KPZU-75 type (with a sawmill concentrator with a diameter of $1.8 \mathrm{~m}$ designed by Tomskgazoochistka LLC, Russia) The following results were obtained: $h=73 \% ; K_{\text {fin }}=960 \mathrm{mg} / \mathrm{m}^{3} ; \Delta P=1500 \mathrm{~Pa}$ [1]. Such low cleaning results led the authors of this work to conclude that it is necessary to replace the technology for burning sunflower husks in vortex furnaces, for example, for its combustion in a fluidized bed or when using fuel pyrolysis.

At a number of oil and fat plants in Ukraine, steam boilers with a steam capacity of $10 \mathrm{t} / \mathrm{h}$ (with ball burning of husks of sunflower and with grate) by Energomashproekt DB (Kyiv, Ukraine) studied the final concentration of ash by cyclones [3].

After gas cleaning in typical $\mathrm{CN}-15$ cyclones with a diameter of $0.7 \mathrm{~m}$, installed after smoke exhausters, the final dust content was - depending on the amount of air suction through the bins of the cleaning system and the dispersion of ash [5, 6].

In the city of Oleksiivka (Belhorod Region, Russia), on four boilers, when burning sunflower husks, bag filters of the Filcon A/C company (Denmark) were introduced using high-temperature glass cloth sleeves with microporous polymer inserts [2]. According to EFKO PJSC (Ukraine), which implemented the new cleaning system, when cleaning gases with high temperature $\left(180 \ldots 220^{\circ} \mathrm{C}\right)$ and significant gas flow rates, high degrees of reliability and operational efficiency were obtained. Moreover, data on the most important technical parameters of the cleaning system (dustiness of gases before and after cleaning, cleaning efficiency, hydraulic resistance, etc.) were not given [2].

In 2014, in Zaporizhzhia (Ukraine), at an oil-fat plant at two boilers with a steam capacity of $25 \mathrm{t} / \mathrm{h}$ each, electric filters designed by Energomashecologiia LLC (Kyiv, Ukraine) of the EGI 43-16-7-6W/S 640-400-2 type were installed when burning sunflower husks [3]. The following data were obtained on each boiler:

- flue gas consumption - $80,000 \mathrm{~m}^{3} / \mathrm{h}$;

- temperature of the gases in front of the electrostatic precipitator $-250{ }^{\circ} \mathrm{C}$;

- dustiness of gases: initial - $6000 \mathrm{mg} / \mathrm{m}^{3}$; final $50 \mathrm{mg} / \mathrm{m}^{3}$;

- cleaning efficiency - $99.17 \%$

In 2016, in the boiler room of Pology Oil Extraction Plant CJSC (Pology, Ukraine), a bag filter of Energomashecologiia LLC design was installed on boiler No. 1 of the TDBWTr 20-23-250 GM type (Ukraine) with a steam capacity of $20 \mathrm{t} / \mathrm{h}$ while burning sunflower husk [3]. According to the test report, the following results were obtained:

- flue gas consumption - $23500 \ldots 36030 \mathrm{~m}^{3} / \mathrm{h}$;

- boiler steam output - 6...12 t/h;

- average final dust content of flue gases $-39.4 \mathrm{mg} / \mathrm{nm}^{3}$.

There is serious doubt about the possibility of using flue gas cleaning technology in bag filters when burning sunflower husks. This is due to the high temperature of the flue gases (more than $200{ }^{\circ} \mathrm{C}$ ) and therefore there is a significant likelihood of fires when burning sunflower husks. In addition, the most expensive material of filter bags in case of technology malfunctions or when sparks can appear can be destroyed at high temperatures, since the maximum permissible gas temperature of bag filter materials is, as a rule, no higher than $280^{\circ} \mathrm{C}$ [7].

In addition, the considerable price of bag and electric filters makes it possible to use cyclones for a considerable period of time to collect ash from flue gases when burning sunflower husks in boilers. This issue remains insufficiently covered and requires further scientific research and industrial implementation.

Concerning the development of the theory of cyclonic ash and dust cleaning, as well as the development and implementation of new cyclone designs, in recent years there is information in the following works:

In [8], the data of analysis and practical evaluation of the efficiency of cyclones with louvered gas outlet are presented. A method for calculating the efficiency of cleaning such cyclones from dust is given. The disadvantage of this is that the conclusions can be used only for cyclones with a louvered gas outlet.

In [9], models are considered for describing the backflow flow field inside a cyclone and dependences for predicting the degree of dust removal. It is noted that although the methods to be considered are successful, it is necessary to develop methods for calculating cyclones and methods for their modernization. 
In [10], the results of a numerical study of the flow of a dust and gas stream in one of the known cyclones are presented. It is shown that particles enter the cyclone from different locations and have different cleaning efficiencies. The disadvantage of this work is that the conclusions can be used only for the given type of cyclones.

Thus, the results of literature analysis allow to conclude that the problem of improving the efficiency of cleaning ash in cyclones of flue gases from burning sunflower husks in steam boilers is practically very little covered. The reason for this is the fact that this combustion technology found application only in Russia and Ukraine only a few years ago. And on the important issue of increasing the degree of gas cleaning from ash in cyclones from the level of $45 \ldots 55 \%$ to the level required by sanitary standards, $89 \ldots 90 \%$, there are no publications at all. That is, there is practically a problem of the need to reduce the final dust content of gases when burning sunflower husks on the grate from boilers from $500 \ldots 900 \mathrm{mg} / \mathrm{m}^{3}$ to the sanitary standards in the European Union and Ukraine $-50-100 \mathrm{mg} / \mathrm{nm}^{3}$ [4]. This requires further research and industrial implementation.

\section{Methods of research}

In this work, using computer and new analytical calculations, the possibility of increasing the overall efficiency of flue gas cleaning from ash when burning sunflower husks in boilers to a level of $90 \%$ instead of $45 \ldots 55 \%$ is substantiated. To do this, turbulence is increased in the zones of interaction of ash particles with the surface of the cyclone and with a «tow» of ash on its surface. Additionally, various flow turbulizers installed on the jet section in the inlet of the cyclone are used.

For analytical calculations of cyclones, a new method is developed and used, based on the significant influence on the efficiency of cleaning the values of the internal Kolmogorov scale of turbulence; pulsating dynamic velocity of the gas stream. Computer calculations are performed using computer technology CFD - Computational Fluid Dynamic certified computer program «SolidWorks-2009» [6], on the calculation complex (KPI). The subject of research is the calculation of the optimal parameters of gas flow turbulence generators, their location in the inlet of the cyclone, and the cleaning efficiency of typical and modernized cyclones. Verification of the results is carried out using a full-scale experiment in the production conditions of the oil and fat plant in cyclones $\mathrm{CN}-15$ with a diameter of $0.7 \mathrm{~m}$

So, the sanitary flue gas cleaning system for the sunflower of the KE 10-14-285 steam boiler operating in the meadow of the Vinnytsia oil and fat factory (Ukraine) consists of:

- group cyclones of the $\mathrm{CN}-15$ type (6 pieces with a diameter of $0.7 \mathrm{~m}$ ) with a common hopper and a lock supplier, the SN-15 smoke exhauster (Ukraine) ( $n=1000 \mathrm{rpm}, N=75 \mathrm{~kW}$ with frequency control of revolutions);

- flue system and chimney.

\section{Research results}

Let's present the data of tests and calculations of computer and analytical efficiencies of the typical cyclone $\mathrm{CN}-15$ and the reconstructed cyclone CN-15-TR (Ukraine).

The calculations are carried out with the following design parameters of cyclones, technological parameters of the gas stream and the physicochemical properties of the ash when burning sunflower husks:

- diameter of cyclones CN-15 (6 pcs.) - $D_{c y c}=0.7 \mathrm{~m}$;

- gas temperature $-t_{g}=200{ }^{\circ} \mathrm{C}$;

- gas velocity in the inlet of the cyclone $-V_{i n p}=18 \mathrm{~m} / \mathrm{s}$;

- average gas velocity in the horizontal section of

the cyclone $-V_{a v}=3.95 \mathrm{~m} / \mathrm{s}$;

- ash density $-p_{a s}=1500 \mathrm{~kg} / \mathrm{m}^{3}$;

- median ash diameter $d_{50}=7$ microns;

- dispersion of the distribution of ash particles in size -

$\sigma_{a}=2$ (dimensionless quantity);

- initial dust content of ash in the gas before the cyclone $-K_{\text {in }}=842 \mathrm{mg} / \mathrm{m}^{3}$.

Analytical calculation of a typical $\mathrm{CN}-15$ cyclone [5]:

- gas density:

$p_{g}=1.29\left(\frac{273}{273+t_{g}}\right)=0.745 \mathrm{~kg} / \mathrm{m}^{3} ;$

- hydraulic resistance of the cyclone:

$\Delta P_{c y c}=\varsigma p_{g}\left(\frac{V_{i n p}{ }^{2}}{2}\right)=160 \cdot 0.745\left(\frac{3.95^{2}}{2}\right)=930 \mathrm{~Pa}$;

- dynamic gas viscosity:

$\mu_{g}=\left(18.2+0.035 \cdot t_{g}\right)=25 \cdot 10^{-6} \frac{\mathrm{kg}}{\mathrm{m} \cdot \mathrm{s}} ;$

- kinematic viscosity of gas:

$v_{g}=\frac{\mu_{g}}{p_{g}}=33.6 \cdot 10^{-6} \frac{\mathrm{kg}}{\mathrm{m} \cdot \mathrm{s}} ;$

- equivalent diameter of the inlet of the cyclone:

$d_{\text {eqv }}=\frac{2 a b}{(a+b)} D_{c y c}=\frac{2 \cdot 0.26 \cdot 0.66 \cdot 0.7}{(0.26+0.66)}=0.261 \mathrm{~m} ;$

- Kolmogorov micro-scale turbulence [5]:

$\lambda_{0}=\left(\frac{v_{g}}{V_{\text {in }}}\right)^{3 / 4}\left(d_{\text {eqv }}\right)^{1 / 4}=$

$=\left(\frac{33.6 \cdot 10^{-6}}{18}\right)^{3 / 4}(0.261)^{1 / 4}=36.1 \cdot 10^{-6} \mathrm{~m}$;

- pulsating dynamic gas flow rate in the inlet pipe of a typical cyclone is calculated according to the empirical dependence established by the author:

$u=\frac{23}{\lambda_{0}}=\frac{23}{36}=0.64 \mathrm{~m} / \mathrm{s}$

- the diameter of the ash particles is captured with an efficiency of $50 \%$ (diameter of the «cut-off»):

$$
\begin{aligned}
& d_{\eta=50}=8.5(0.42)^{u}\left(\frac{D_{c y c}}{0.6}\right)^{1 / 4}\left(\frac{\mu_{g} \cdot 1930}{22 \cdot 10^{-6} \cdot p_{a s}}\right)^{1 / 2}= \\
& =8.5(0.42)^{0.64}\left(\frac{0.7}{0.6}\right)^{1 / 4}\left(\frac{25 \cdot 10^{-6} \cdot 1930}{22 \cdot 10^{-6} \cdot 1500}\right)^{1 / 2}=
\end{aligned}
$$$$
=6.13 \text { microns; }
$$ 
- the parameter value of the fractional degree of cleaning «t» [5]:

$t=\frac{\lg d_{50}-\lg d_{\eta 50}}{\sqrt{\lg ^{2} \sigma_{a s}+\lg ^{2} \sigma_{a}}}=0.125 ;$

- the value of the total cleaning degree [5]:

$$
\eta_{\text {com }}=\Phi(t)=\frac{100}{\sqrt{2 \pi}} \int e^{-\frac{t^{2}}{2}} \mathrm{~d} t
$$

which is determined by the following empirical dependencies [5]:

$$
\begin{aligned}
& \eta_{c o m}=50+44 t-10(t)^{2},\left(\text { for } 50 \%<\eta_{c o m}<98 \%\right), \\
& \eta_{c o m}=105.4-\frac{15}{t},\left(\text { for } \eta_{c o m}>98 \%\right) \\
& \eta_{c o m}=50+44(0.125)-10(0.125)^{2}=55.34 \% ;
\end{aligned}
$$

- final dust content of gases with ash after cleaning in typical cyclones $\mathrm{CN}-15$ :

$$
K_{\text {fin }}=K_{\text {in }}\left(1-\eta_{\text {com }}\right)=842(1-0.5534)=376 \mathrm{mg} / \mathrm{m}^{3} .
$$

Table 1 shows the analytical calculated values of the cleaning efficiency in a typical cyclone CN-15 (at $K_{i n}=842 \mathrm{mg} / \mathrm{m}^{3}$ ) for a wider range of ash dispersion.

Table 1

The efficiency of ash cleaning in a conventional cyclone CN-15 steam boiler KE 10-14-285 when burning husks of sunflower ail and fat plant

\begin{tabular}{|l|c|c|c|c|c|c|c|c|c|c|}
\hline$d_{50}$, microns & 5 & 6 & $\mathbf{7}$ & 8 & 9 & 10 & 12 & 15 & 20 & 25 \\
\hline$\eta_{\text {com },} \%$ & 43 & 50 & $\mathbf{5 5}$ & 60 & 64.4 & 68 & 73.9 & 80 & 86.9 & 90.5 \\
\hline$K_{\text {in, }} \mathrm{mg} / \mathrm{m}^{3}$ & 842 & 842 & $\mathbf{8 4 2}$ & 842 & 842 & 842 & 842 & 842 & 842 & 842 \\
\hline$K_{\text {fin, }}, \mathrm{mg} / \mathrm{m}^{3}$ & 480 & 421 & $\mathbf{3 7 6}$ & 337 & 300 & 270 & 220 & 168 & 110 & 80 \\
\hline
\end{tabular}

Note: the given test data under industrial conditions for $d_{50}=7$ microns; $\sigma_{a s}=2$

Data in Table 1 shows that in a typical cyclone $\mathrm{CN}-15$, the cleaning efficiency is insufficient to achieve standard values $K_{\text {fin }}=50 \mathrm{mg} / \mathrm{m}^{3}$ [4], therefore, the low-cost upgrade of cyclones $\mathrm{CN}-5$ with a diameter of $0.7 \mathrm{~m}$ at discharge was performed after smoke exhaust for the conditions of the oil and fat plant when burning sunflower husks in the boiler KE 10-14-285.

Analytical calculation of the upgraded cyclone CN-15-TR with RAMA-type turbulizers (Ukraine). The modernization of cyclones CN-15 (0.7 $\mathrm{m}$ in diameter) for the conditions of the oil and fat plant when burning sunflower husks in the boiler KE 10-14-285 consisted of installing turbine generators of the RAMA type on the jet section of cyclones. The latter are equipped with intersections with strip metal with a width of $25 \mathrm{~mm}$ and a thickness of $5 \mathrm{~mm}$ - three vertical and five horizontal intersections with a living section area (referred to the area of the cyclone inlet pipe) $\left.f_{\text {liv.cyc }}=0.317\right)[5,7]$.

The calculation of the upgraded cyclone CN-15-TR (Ukraine) was made for the conditions of the oil and fat plant when burning sunflower husks in the boiler KE 10-14-285 (Ukraine). The gas temperature before the cyclones is $200{ }^{\circ} \mathrm{C}$, the average gas velocity in the horizontal section of the cyclones is $3.95 \mathrm{~m} / \mathrm{s}$, the ash density is $1500 \mathrm{~kg} / \mathrm{m}^{3}, d_{\eta 50}=7 \mu \mathrm{m} ; \sigma_{a}=2$. The calculation is performed in the following sequence:

- coefficient of hydraulic resistance of the cyclone:

$$
\begin{aligned}
& \varsigma^{t . g . \mathrm{CN}-15}=\frac{\varsigma^{\text {typCN-15}}\left(0.78 f_{\text {liv.cyc }}+0.22\right)}{f_{\text {liv.cyc }}}= \\
& =\frac{160(0.78 \cdot 0.317+0.22)}{0.317}=236 ;
\end{aligned}
$$

- gas density:

$p_{g}=1.29\left(\frac{273}{273+t_{g}}\right)=1.29\left(\frac{273}{273+200}\right)=0.745 \frac{\mathrm{kg}}{\mathrm{m} \cdot \mathrm{s}} ;$

- hydraulic resistance of the cyclone:

$\Delta P_{c y c}=\varsigma p_{g} \frac{\left(V_{a v}\right)^{2}}{2}=236 \cdot 0.745 \frac{(3.95)^{2}}{2}=1370 \mathrm{~Pa} ;$

- the turbulence degree of the gas stream in the inlet pipe with a turbulence generator installed by the author during computer simulation of the dependence:

$T_{u t . g}=93 \cdot(0.065)^{f_{\text {iti.c.cyc }}}=39.1 \%$;

- the «cut-off» diameter or the diameter of the ash particles, which are captured with an efficiency of $50 \%$, calculated according to the dependence established by the author during computer simulation:

$$
\begin{aligned}
& \left(d_{\eta=50}\right)_{t . g .}=\left(d_{\eta=50}\right)_{t y p}\left(\frac{T_{u t y p}}{T_{u t . g .}}\right)^{0.52}\left(\frac{D_{c y c}}{0.6}\right)^{1 / 4} \times \\
& \times\left(\frac{v_{g} \cdot 1930 \cdot 3.5}{22 \cdot 10^{-6} \cdot p_{a s} \cdot V_{a v}}\right)^{1 / 2}=6.13\left(\frac{3.56}{39.1}\right)^{0.52}\left(\frac{0.7}{0.6}\right)^{1 / 4} \times \\
& \times\left(\frac{25 \cdot 10^{-6} \cdot 1930 \cdot 3.5}{22 \cdot 10^{-6} \cdot 1500 \cdot 3.95}\right)^{1 / 2}=2.196 \text { microns, }
\end{aligned}
$$

where

$$
T_{\text {utyp }}=\left(\frac{u}{V_{\text {inp }}}\right) \cdot 100=\left(\frac{0.64}{18}\right) \cdot 100=3.56 \% ;
$$

- the parameter «t» fractional degree of cleaning [5] is calculated according to the dependence:

$$
t=\frac{\lg d_{50}-\lg \left(d_{\eta 50}\right)_{t . g .}}{\sqrt{\lg ^{2} \sigma_{a s}+\lg ^{2} \sigma_{\eta}}}=1.0907
$$

- the value of the total degree of cleaning is calculated according to the dependence [5]:

$$
\begin{aligned}
& \eta_{\text {com }}=50+44 t-10(t)^{2},(\text { for } t<2.054), \\
& \eta_{\text {com }}=105.4-\frac{15}{t},(\text { for } t>2.054), \\
& \eta_{\text {com }}=50+44(0.125)-10(0.125)^{2}=55.34 \% ;
\end{aligned}
$$


- final dust content of gases with ash after cleaning in the cyclone $\mathrm{CN}-15-\mathrm{TR}$ :

$$
K_{\text {fin }}=K_{\text {in }}\left(1-\eta_{\text {com }}\right)=842(1-0.861)=117 \mathrm{mg} / \mathrm{m}^{3} .
$$

After gas cleaning in a typical cyclone $\mathrm{CN}-15$, the final dust content was $379 \mathrm{mg} / \mathrm{m}^{3}$, and in a modernized cyclone CN-15-TR, $117 \mathrm{mg} / \mathrm{m}^{3}$, that is, 3.2 times less. According to the final dust content of gases in the cyclone $\mathrm{CN}-15-\mathrm{TR}$, the requirements of the countries of the European Union and Ukraine, which are $100 \mathrm{mg} / \mathrm{m}^{3}$ for old boilers, are practically fulfilled [4].
Fig. 1, 2 show the results of computer CFD modeling using a licensed application software package for numerical simulation of turbulent flows «COSMOS Flo Works» at the National Technical University «Kyiv Polytechnic Institute».

The data are used to determine the efficiency of cleaning the gas stream from aerosols in a typical cyclone $\mathrm{CN}-15$ (Ukraine) and in a cyclone CN-15-TR modernized according to [5, 7] (Ukraine).

The total ablation of ash particles in the modernized cyclone $\mathrm{CN}-15-\mathrm{TR}$, in comparison with the usual cyclone $\mathrm{CN}-15$, is decreased by 3.2 times.

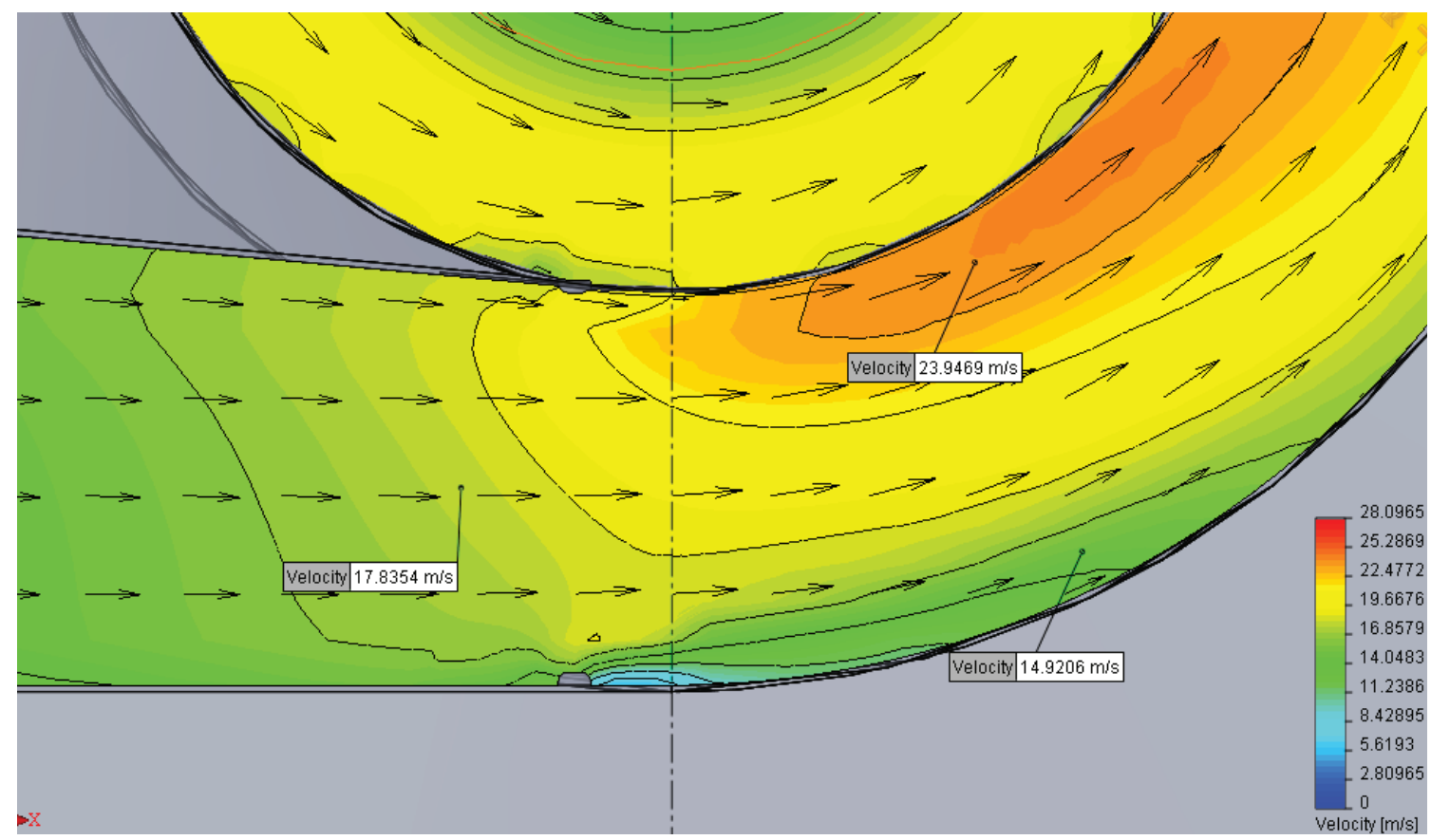

Fig. 1. The distribution of gas flow velocity of a typical cyclone CN-15 (diameter $0.7 \mathrm{~m}$ ) for the conditions of oil and fat plant

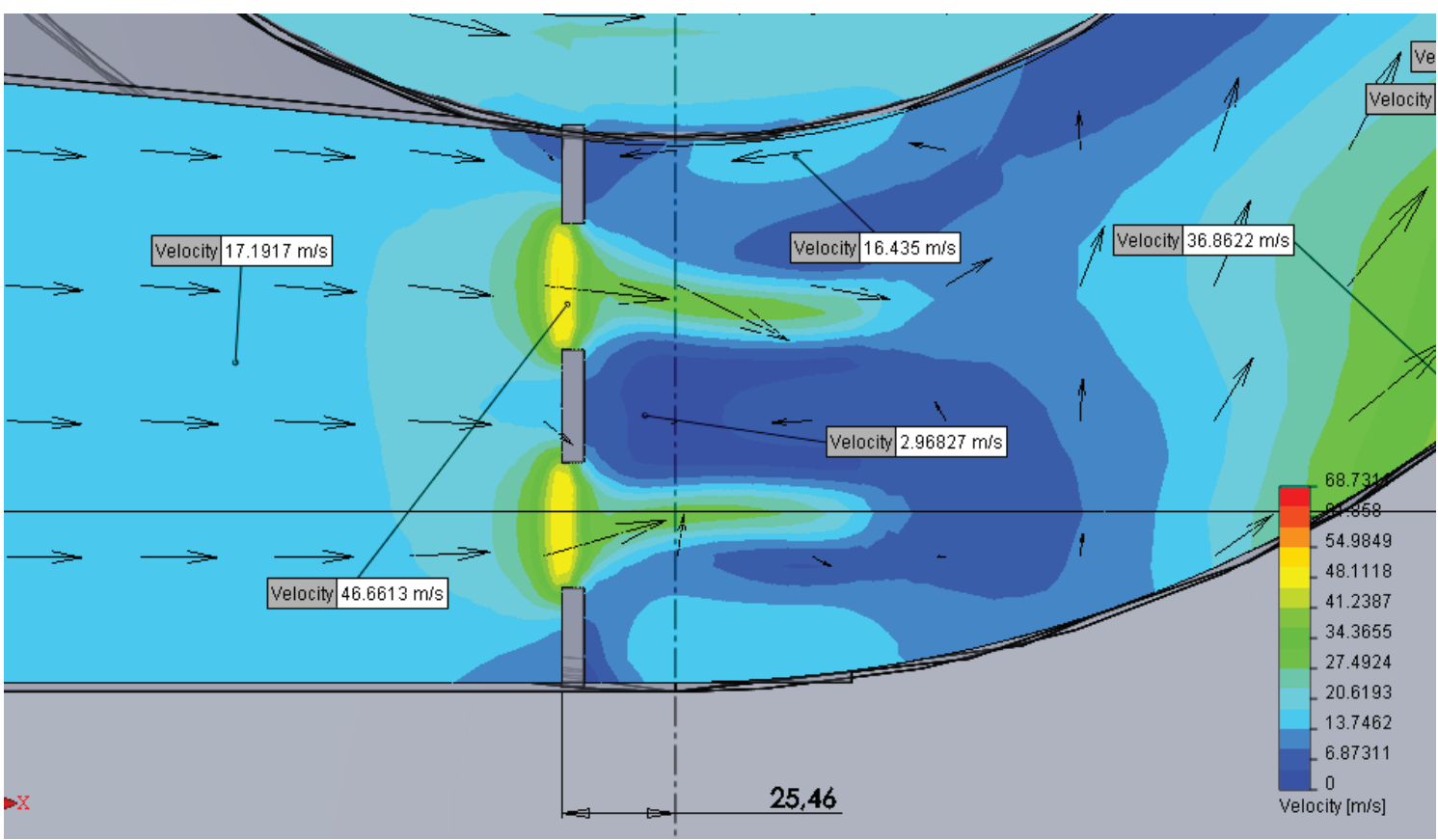

Fig. 2. Distribution of the gas flow velocity of the cyclone [N-15-TR modernized according to [7] (diameter $0.7 \mathrm{~m}$ ) for the conditions of the oil and fat plant 


\section{SWOT analysis of research results}

Strengths. The strengths of the cleaning technology proposed in the work include the following:

- the practical lack of capital costs;

- the possibility of its implementation even when the boiler;

- the absence of the need to replace inefficient cyclones with more efficient, but also more valuable equipment; - the invariability of metal consumption and performance of the cleaning system;

- a decrease of more than 3 times the ash removal from cyclones on finely dispersed ash of the fourth dispersion group with a median diameter of ash particles of $1 . . .10$ microns;

- a significant reduction in the time taken to carry out analytical and computer calculations of cyclones and to increase their accuracy.

Weaknesses. The weaknesses of the cleaning technology proposed in this work include only a slight increase in energy costs, which, however, do not exceed, as a rule, $40 \ldots 50 \%$ of the existing ones.

Opportunities. A promising area for further research is the study of the possible application of the proposed technology for the modernization of treatment systems for the needs of other industries. For example, Venturi coagulators can be used in thermal power plants when burning various types of fuel in steam boilers, in wet and dry dust collectors of various industries, and the like.

The use of the research results obtained in the proposed work may be interesting not only for Ukraine, since it allows one to modernize ordinary cyclones that are used for gas cleaning in many countries.

Threats. When implementing the results of the research, additional costs will be required, but they will be minimal.

\section{Conclusions}

1. The optimal parameters of gas flow turbulence generators, their locations in the inlet pipe of a new cyclone, and the cleaning efficiency of typical and modernized cyclones were calculated. The cyclone $\mathrm{CN}-15$ modernization method has been developed for the conditions of the oil and fat plant when husks are burned in the boiler KE 10-14-285. It consists in installing RAMA-type turbulence generators on the jet section of cyclones. The latter are equipped with three vertical and five horizontal intersections with strip metal $25 \mathrm{~mm}$ wide and $5 \mathrm{~mm}$ thick.
2. An experimental verification of the introduction of a new ash cleaning technology during the burning of sunflower husks and the adequacy of computer and analytical methods for calculating the cleaning efficiency are carried out. Before modernization in a typical cyclone $\mathrm{CN}-15$ after gas cleaning, the final dust content is $379 \mathrm{mg} / \mathrm{m}^{3}$. In the cyclone $\mathrm{CN}-15$-TR modernized according to the proposed technology $-117 \mathrm{mg} / \mathrm{m}^{3}$, that is, 3.2 times less.

\section{References}

1. Vasilevskii, M. V., Razva, A. S., Zykov, E. G. et. al. (2013). Osobennosti ochistki dymovykh gazov ot zoly-unosa inercionnymi apparatami za kotlom KE-16-23-370 GDV s vikhrevoi topkoi szhiganiia luzgi podsolnechnika. Promyshlennaia energetika, 1, 49-53.

2. «EFKO» moderniziruet proizvodstvo v sootvetstvii s mirovymi ekologicheskimi standartami (2013). Available at: http://www. efko.ru/press-centr/relizy/2750/

3. Stroitelstvo dvukh gazoochistok za kotlami No. 10, 11, szhigaiuschimi luzgu podsolnechnika (2008). Energomashekologiia. Available at: http://www.em-eco.net.ua/vnedreniya/szhiganiebiomassy/zmzhk-kratko/

4. Pro zatverdzhennia normatyviv hranychnodopustymykh oykydiv zabrudniuiuchykh rechooyn iz statsionarnykh dzherel (2006). Nakaz Minpryrody Ukrainy No. 309. 27.06.06. Available at: https://zakon.rada.gov.ua/laws/card/z0912-06

5. Priemov, S. I. (2014). Metody rascheta $i$ pooysheniia effektivnosti ochistki ciklonnykh pyleulovitelei. Kyiv: Kafedra, 132.

6. Aliamovskii, A., Sobachkin, A., Odincov, E., Kharitonovich, A., Ponomarev, N. (2008). SolidWorks 2007/2008. Kompiuternoe modelirovanie v inzhenernoi praktike. Saint Petersburg, 1040.

7. Priiomov, S. I., Shulga, S. M., Rizhov, I. M., Rizhov, V. I. (2014) Pat. No. 105368 UA. Pilovlovliuvalnii pristrii ta porozhnista vstavka dlia pilovlovliuvalnogo pristroiu. MPK: B01D 45/12. No. a 2011 05185. declareted: 26.04.2011; published: 12.05.2014, Bul. No. 9.

8. Slobodian, S. M., Kuc, V. P. (2014). Sistemy pyleulavlivaniia $\mathrm{s}$ inercionnymi apparatami $\mathrm{v}$ proizvodstve stroitelnykh materialov. Bezopasnost zhiznedeiatelnosti, 8, 55-59.

9. Cortes, C., Gil, A. (2007). Modeling the gas and particle flow inside cyclone separators. Progress in Energy and Combustion Science, 33 (5), 409-452. doi: http://doi.org/10.1016/ j.pecs.2007.02.001

10. Wang, B., Xu, D. L., Chu, K. W., Yu, A. B. (2006). Numerical study of gas-solid flow in a cyclone separator. Applied Mathematical Modelling, 30 (11), 1326-1342. doi: http://doi.org/ 10.1016/j.apm.2006.03.011

Ryzhov Volodymyr, Postgraduate Student, Department of Computer Engineering, Open International Human Development University «Ukraine», Kyiv, Ukraine, ORCID: http://orcid.org/00000001-7521-6840 